\title{
UPAYA PEMERINTAH DAERAH DALAM PENANGGULANGAN STUNTING DI PROVINSI KEPULAUAN BANGKA BELITUNG
}

\author{
Rini Archda Saputri \\ Universitas Bangka Belitung \\ rini-as@ubb.ac.id
}

\begin{abstract}
Abstrak
Indonesia sedang menghadapi tantangan besar terkait kualitas sumber daya manusia dengan prevalensi balita stunting sebesar 30,8\% pada tahun 2018. Pemerintah melalui Tim Nasional Percepatan Penanggulangan Kemiskinan (TNP2K) telah menetapkan 100 kabupaten/kota prioritas untuk intervensi anak kerdil (stunting). 2 daerah diantaranya adalah Kabupaten Bangka dan Kabupaten Bangka Barat di Provinsi Kepulauan Bangka Belitung. Penelitian ini bertujuan untuk mengidentifikasi dan menganalisis upaya pemerintah daerah dalam penanggulangan stunting pada dua daerah tersebut. Metode penelitian dilakukan secara kualitatif melalui wawancara mendalam dan diskusi kelompok terfokus yang melibatkan para pemangku kepentingan hingga implementer program di tingkat masyarakat (puskesmas) dan desa/kelurahan. Hasil penelitian menujukkan bahwa, selain programprogram yang berasal dari pemerintah pusat, Kabupaten Bangka dan Bangka Barat telah memiliki program-program inovasi sendiri dalam upaya percepatan penurunan/penanggulangan stunting di daerahnya. Namun demikian, masih dibutuhkan waktu/proses untuk program-program tersebut dapat terlihat secara nyata pelaksanaannya dan terlihat signifikansi hasilnya. Untuk saat ini, program-program penanggulangan stunting yang telah dilakukan diantaranya adalah; Pemberian Makanan Tambahan (PMT) pada Balita dan Ibu Hamil, Pemberian Tablet Tambah Darah (TTD) pada remaja putri dan ibu hamil, peningkatan cakupan imunisasi dasar lengkap pada bayi dan balita, pemberian vitamin A pada balita, dan pemberian zinc pada kasus diare terutama pada ibu hamil dan balita.
\end{abstract}

Kata Kunci: intervensi, penanggulangan, stunting

\begin{abstract}
Indonesia is facing great challenges related to the quality of human resources with the prevalence of stunting toddlers of $30.8 \%$ in the year 2018. The Government through the national Team of acceleration reduction in poverty (TNP2K) has set 100 districts/cities priority for stunting interventions. Two of them are Bangka district and West Bangka Regency in Bangka Belitung Islands province. The research aims to identify and analyze local government efforts in the stunting response of the two areas. The research method is qualitative conducted through in-depth interviews and focused group discussions involving stakeholders to the implementer program at community level (Puskesmas) and village/village. The results showed that, in addition to programs originating from the central government, Bangka and West Bangka districts have their own innovation programs in the acceleration of the stunting decline/countermeasures in the region. Nevertheless, it still takes time for these programs can be seen in real execution and visible significance of the results. For the moment, the stunting programs that have been carried out include; Additional food delivery (PMT) in infants and pregnant mothers, administering the blood tablets (TTD) in young women and Pregnant mothers, increased coverage of basic immunisation in infants and toddlers, administering vitamin $A$ in infants, and zinc in cases of diarrhea especially in pregnant women and toddlers.
\end{abstract}

Keywords: intervention, management, stunting 


\section{PENDAHULUAN}

Kejadian balita pendek atau biasa disebut dengan stunting merupakan salah satu masalah gizi yang dialami oleh balita di dunia saat ini. Pada tahun 2017, 22,2\% atau sekitar 150,8 juta balita di dunia mengalami stunting. Pada tahun 2017, lebih dari setengah balita stunting di dunia berasal dari Asia (55\%) sedangkan lebih dari sepertiganya (39\%) tinggal di Afrika. Dari 83,6 juta balita stunting di Asia, proporsi terbanyak berasal dari Asia Selatan (58,7\%) dan proporsi paling sedikit di Asia Tengah (0,9\%). Data prevalensi balita stunting yang dikumpulkan World Health Organization (WHO) menunjukkan bahwa Indonesia termasuk ke dalam negara ketiga dengan prevalensi tertinggi di regional Asia Tenggara/South-East Asia Regional (SEAR). Rata-rata prevalensi balita stunting di Indonesia tahun 2005-2017 adalah 36,4\% (Utama n.d.).

Tujuan reformasi sebenarnya adalah mencita-citakan sistem pemerintahan yang baik, bersih, anti korupsi, kolusi dan nepotisme (KKN). Cita-cita tersebut berimplikasi kepada tingkat kesejahteraan dan taraf hidup masyarakat dan tentunya mengangkat derajat dan martabat bangsa Indonesia di kancah internasional. Namun hal tersebut sangat kontradiktif dengan apa yang dirasakan oleh masyarakat (Syamsuadi 2017).

Saat ini, Indonesia merupakan salah satu negara dengan prevalensi stunting yang cukup tinggi dibandingkan dengan negara-negara berpendapatan menengah lainnya. Balita/Baduta (Bayi dibawah usia Dua Tahun) yang mengalami stunting akan memiliki tingkat kecerdasan tidak maksimal, menjadikan anak menjadi lebih rentan terhadap penyakit dan di masa depan dapat beresiko pada menurunnya tingkat produktivitas. Pada akhirnya secara luas stunting akan dapat menghambat pertumbuhan ekonomi, meningkatkan kemiskinan dan memperlebar ketimpangan. Situasi ini jika tidak diatasi dapat memengaruhi kinerja pembangunan Indonesia baik yang menyangkut pertumbuhan ekonomi, kemiskinan dan ketimpangan (TNP2K 2017).

Pengalaman dan bukti internasional menunjukkan bahwa stunting dapat menghambat pertumbuhan ekonomi dan menurunkan produktivitas pasar kerja, sehingga mengakibatkan hilangnya 11\% GDP (Gross Domestic Products) serta mengurangi pendapatan pekerja dewasa hingga 20\%. Selain itu, stunting juga dapat berkontribusi pada melebarnya kesenjangan/inequality, sehingga mengurangi 10\% 
dari total pendapatan seumur hidup dan juga menyebabkan kemiskinan antargenerasi (TNP2K 2017).

Kerdil (Stunting) pada anak mencerminkan kondisi gagal tumbuh pada anak balita (bawah 5 Tahun) akibat dari kekurangan gizi kronis, sehingga anak menjadi terlalu pendek untuk usianya. Kekurangan gizi kronis terjadi sejak bayi dalam kandungan hingga usia dua tahun. Dengan demikian periode 1000 hari pertama kehidupan seyogyanya mendapat perhatian khusus karena menjadi penentu tingkat pertumbuhan fisik, kecerdasan, dan produktivitas seseorang di masa depan (TNP2K 2017).

Pemerintah melalui Tim Nasional Percepatan Penanggulangan Kemiskinan (TNP2K) telah menetapkan 100 kabupaten/kota prioritas penanggulangan stunting. Daerah prioritas atau daerah yang menjadi lokus utama intervensi stunting adalah daerah yang memiliki angka prevalensi stunting tinggi dibandingkan dengan daerah lainnya. Hal ini berkaitan dengan anggaran yang dialokasikan untuk penanggulangan stunting. Daerah priotitas penanggulangan stunting memiliki anggaran khusus yang memang diperuntukkan bagi program-program percepatan penaggulangan dan pencegahan stunting.

Di Provinsi Kepulauan Bangka Belitung, terdapat 2 daerah yang termasuk kedalam 100 daerah prioritas penanggulangan stunting, yaitu Kabupaten Bangka dan Bangka Barat. Penelitian ini mencoba mengidentifikasi dan menganalisa berbagai upaya yang dilakukan pemerintah daerah Kabupaten Bangka dan Bangka Barat dalam menurunkan prevalensi stunting di daerahnya.

\section{STUDI LITERATUR}

\section{Penyebab Stunting}

Stunting disebabkan oleh faktor multi dimensi dan tidak hanya disebabkan oleh faktor gizi buruk yang dialami oleh ibu hamil maupun anak balita. Intervensi yang paling menentukan untuk dapat mengurangi prevalensi stunting oleh karenanya perlu dilakukan pada 1.000 Hari Pertama Kehidupan (HPK) dari anak balita. Beberapa faktor yang menjadi penyebab stunting adalah; praktek pengasuhan yang kurang baik, termasuk kurangnya pengetahuan ibu mengenai kesehatan dan gizi sebelum dan pada masa kehamilan, serta setelah melahirkan. Masih terbatasnya 
layanan kesehatan termasuk layanan ANC-Ante Natal Care (pelayanan kesehatan untuk ibu selama masa kehamilan) Post Natal Care dan pembelajaran dini yang berkualitas, masih kurangnya akses rumah tangga/keluarga ke makanan bergizi, kurangnya akses rumah tangga/keluarga ke makanan bergizi, kurangnya akses ke air bersih dan sanitasi (TNP2K 2017).

\section{Kerangka Intervensi Stunting di Indonesia}

Kerangka intervensi stunting yang dilakukan oleh Pemerintah Indonesia terbagi menjadi dua, yaitu Intervensi Gizi Spesifik dan Intervensi Gizi Sensitif. Kerangka pertama adalah Intervensi Gizi Spesifik. Ini merupakan intervensi yang ditujukan kepada anak dalam 1000 Hari Pertama Kehidupan (HPK) dan berkontribusi pada $30 \%$ penurunan stunting. Kerangka kegiatan intervensi gizi spesifik umumnya dilakukan pada sektor kesehatan. Intervensi ini juga bersifat jangka pendek dimana hasilnya dapat dicatat dalam waktu relatif pendek. Kegiatan yang idealnya dilakukan untuk melaksanakan Intervensi Gizi Spesifik dapat dibagi menjadi beberapa intervensi utama yang dimulai dari masa kehamilan ibu hingga melahirkan balita, yaitu; Intervensi gizi spesifik dengan sasaran ibu hamil, intervensi gizi spesifik dengan sasaran ibu menyusui dan anak usia 0-6 bulan, Intervensi gizi spesifik dengan sasaran ibu menyusui dan anak usia 7-23 bulan (TNP2K 2017).

Kerangka intervensi stunting yang direncanakan oleh pemerintah yang kedua adalah Intervensi Gizi Sensitif. Kerangka ini idealnya dilakukan melalui berbagai kegiatan pembangunan diluar sektor kesehatan dan berkontribusi pada $70 \%$ intervensi stunting. Sasaran dari intervensi gizi sensitif adalah masyarakat secara umum dan tidak khusus ibu hamil dan balita pada 1000 Hari Pertama Kehidupan/HPK. Kegiatan terkait Intervensi Gizi Sensitif dapat dilaksanakan melalui beberapa kegiatan yang umumnya makro dan dilakukan secara lintas Kementerian dan Lembaga. Ada 12 kegiatan yang dapat berkontribusi pada penurunan stunting melalui Intervensi Gizi Spesifik sebagai berikut:

1. Menyediakan dan memastikan akses terhadap air bersih

2. Menyediakan dan memastikan akses terhadap sanitasi

3. Melakukan fortifikasi bahan pangan 
4. Menyediakan akses kepada layanan kesehatan dan Keluarga Berencana (KB)

5. Menyediakan Jaminan Kesehatan Nasional (JKN)

6. Menyediakan Jaminan Persalinan Universal (Jampersal)

7. Memberikan pendidikan pengasuhan pada orang tua

8. Memberikan Pendidikan Anak Usia Dini (PAUD) Universal

9. Memberikan pendidikan gizi masyarakat

10. Memberikan edukasi kesehatan seksual dan reproduksi serta gizi pada remaja

11. Menyediakan bantuan dan jaminan sosial bagi keluarga miskin

12. Meningkatkan ketahanan pangan dan gizi

Kedua kerangka Intervensi Stunting diatas sudah direncanakan dan dilaksanakan oleh Pemerintah Indonesia sebagai bagian dari upaya nasional untuk mencegah dan mengurangi prevalensi stunting (TNP2K 2017).

\section{Program Intervensi Stunting yang Dicanangkan Pemerintah}

Pemerintah Indonesia telah banyak mengeluarkan paket kebijakan dan regulasi terkait intervensi stunting. Di samping itu, kementerian/lembaga (K/L) juga sebenarnya telah memiliki program, baik terkait intervensi gizi spesifik maupun intervensi gisi sensitif, yang potensial untuk menurunkan stunting. Intervensi Program Gizi Spesifik dilakukan oleh Kementerian Kesehatan (Kemenkes) melalui Pusat Kesehatan Masyarakat (Puskesmas) dan Pos Pelayanan Terpadu (Posyandu) melalui Gerakan 1000 Hari Pertama Kehidupan (HPK). Adapun beberapa program gizi spesifik yang telah dilakukan oleh pemerintah dapat diidentifikasi sebagai berikut:

1. Program terkait intervensi dengan sasaran ibu hamil, yang dilakukan melalui beberapa program/kegiatan berikut:

a) Pemberian makanan tambahan pada ibu hamil untuk mengatasi kekurangan energi dan protein kronis

b) Program untuk mengatasi kekurangan zat besi dan asam folat

c) Program untuk mengatasi kekurangan iodium

d) Pemberian obat cacing untuk menanggulangi kecacingan pada ibu hamil 
e) Program untuk melindungi ibu hamil dari malaria

Jenis kegiatan yang telah dan dapat dilakukan oleh pemeritah baik di tingkat nasional maupun di tingkat lokal meliputi pemberian suplementasi besi folat minimal 90 tablet, memberikan dukungan kepada ibu hamil untuk melakukan pemeriksaan kehamilan minimal 4 kali, memberikan imunisasi Tetanus Toksoid (TT), pemberian makanan tambahan pada ibu hamil, melakukan upaya untuk penanggulangan cacingan pada ibu hamil, dan memberikan kelambu serta pengobatan bagi ibu hamil yang positif malaria.

2. Program yang menyasar Ibu Menyusui dan Anak Usia 0-6 bulan, termasuk diantaranya mendorong IMD/Inisiasi Menyusui Dini melalui pemberian ASI jolong/colostrum dan memastikan edukasi kepada ibu untuk terus memberikan ASI Ekslusif kepada anak balitanya. Kegiatan terkait termasuk memberikan pertolongan persalinan oleh tenaga kesehatan, Inisiasi Menyusi Dini (IMD), promosi menyusui ASI ekslusif (konseling individu dan kelompok), imunisasi dasar, pantau tumbuh kembang secara rutin setiap bulan, dan penanganan bayi sakit secara tepat.

3. Program Intervensi yang ditujukan dengan sasaran Ibu Menyusui dan Anak Usia 7-23 bulan, dengan mendorong penerusan pemberian ASI hingga usia 23 bulan didampingi oleh pemberian MP-ASI, menyediakan obat cacing, menyediakan suplementasi zinc, melakukan fortifikasi zat besi ke dalam makanan, memberikan perlindungan terhadap malaria, memberikan imunisasi lengkap, dan melakukan pencegahan dan pengobatan diare.

Selain itu, beberapa program lainnya adalah Pemberian Makanan Tambahan (PMT) Balita Gizi Kurang oleh Kementerian Kesehatan/Kemenkes melalui Puskesmas dan Posyandu. Program terkait meliputi pembinaan Posyandu dan penyuluhan serta penyediaan makanan pendukung gizi untuk balita kurang gizi pada usia 6-59 bulan berbasis pangan lokal (misalnya melalui Hari Makan Anak/HMA). Anggaran program berasal dari Bantuan Operasional Kesehatan (BOK) - Dana Alokasi Khusus (DAK) Non Fisik sebesar Rp. 200.000.000 per tahun per puskemas di daerahnya masing-masing (TNP2K 2017). 
Sedangkan terkait dengan intervensi gizi sensitif, yang telah dilakukan oleh pemerintah melalui $\mathrm{K} / \mathrm{L}$ terkait beberapa diantaranya adalah kegiatan sebagai berikut:

1. Menyediakan dan memastikan akses pada air bersih melalui program PAMSIMAS (Penyediaan Air Bersih dan Sanitasi Berbasis Masyarakat)

2. Menyediakan dan memastikan akses pada sanitasi melalui kegiatan Sanitasi Total Berbasis Masyarakat (STBM)

3. Melakukan fortifikasi bahan pangan (garam, terigu, dan minyak goreng)

4. Menyediakan akses kepada layanan kesehatan dan Keluarga Berencana (KB)

5. Menyediakan Jaminan Kesehatan Nasional (JKN)

6. Menyediakan Jaminan Persalinan Universal (Jampersal)

7. Memberikan pendidikan pengasuhan pada orang tua

8. Memberikan Pendidikan Anak Usia Dini (PAUD) Universal

9. Memberikan pendidikan gizi masyarakat

10. Memberikan edukasi kesehatan seksual dan reproduksi serta gizi pada remaja

11. Menyediakan bantuan dan jaminan sosial bagi keluarga miskin, misalnya melalui Program Subsidi Beras Masyarakat Berpenghasilan Rendah (Raskin/Rastra) dan Program Keluarga Harapan (PKH)

12. Meningkatkan ketahanan pangan dan gizi

Berdasarkan program-program tersebut, tampak bahwa telah banyak upaya yang dilakukan oleh pemerintah dalam menurunkan prevalensi stunting yang tentunya disertai dengan alokasi anggaran yang tidak sedikit. Data dari Riset Kesehatan Dasar (Riskesdas) menunjukkan bahwa angka prevalensi stunting pun telah mengalami penurunan dari 37,2\% pada tahun 2013 menjadi $30,8 \%$ pada tahun 2018. Namun demikian, penurunan tersebut masih jauh dari yang ditargetkan.

\section{METODE PENELITIAN}

Jenis penelitian ini adalah kualitatif. Metode pengumpulan data dilakukan melalui wawancara mendalam dan diskusi kelompok terfokus (focus group discussion) - 
yang melibatkan pemangku kepentingan di tingkat provinsi dan kabupaten, hingga pelaksana program di tingkat masyarakat - kecamatan/ pusat kesehatan masyarakat (puskesmas) dan desa/kelurahan.

Wawancara mendalam (indepth interview) dengan para pemangku kepentingan di level provinsi dan kabupaten yang bidang pekerjaannya terkait dengan program/kegiatan yang berhubungan dengan penanggulangan stunting. $\mathrm{Di}$ tingkat provinsi, wawancara pemangku kepentingan dilakukan untuk menggali program intervensi stunting yang telah dilakukan di level provinsi dan bagaimana mekanisme pelaksanaannya terkait dengan hubungan pemerintah provinsi dengan pusat dan dengan pemerintah kabupaten, serta bagaimana pemerintah provinsi memastikan pelaksanaan intervensi terkait stunting di kabupaten/kota di wilayahnya.

Di tingkat kabupaten, wawancara pemangku kepentingan dilakukan untuk menggali program intervensi stunting yang telah dilakukan di level kabupaten dan bagaimana mekanisme pelaksanaannya terkait dengan hubungan pemerintah kabupaten dengan pemerintah provinsi, serta bagaimana pemerintah kabupaten memastikan pelaksanaan intervensi terkait penanggulangan stunting di wilayahnya.

Di tingkat kecamatan, wawancara pemangku kepentingan dilakukan untuk menilai secara langsung bagaimana implementasi intervensi terkait penanggulangan stunting dilaksanakan hingga dirasakan manfaatnya di tingkat masyarakat. Wawancara ini akan secara khusus menggali berbagai tantangan dan dukungan yang dihadapi oleh pelaksana program yang berada di lini terdepan yang secara langsung melayani masyarakat.

Diskusi kelompok terfokus (Focus Group Discussion/FGD) dilakukan di tingkat kabupaten/kota, kecamatan dan desa. Secara umum, diskusi kelompok bertujuan untuk mengkonfirmasi informasi mengenai penanggulangan stunting yang didapat melalui proses wawancara. Sementara itu, di tingkat desa, FGD secara khusus ditujukan untuk mengkonfirmasi efektivitas program yang dilaksanakan hingga level terkecil di masyarakat.

\section{PEMBAHASAN}

Pembagian Tugas antara Provinsi dan Kabupaten Terkait Upaya Penanggulangan Stunting di Provinsi Kepulauan Bangka Belitung 
Upaya penanggulangan stunting haruslah dilakukan secara komprehensif dan bersinergi antara pemerintah pusat, pemerintah provinsi, dan pemerintah kabupaten/kota. Adapun pembagian tugas antara provinsi dan kabupaten/kota terkait upaya penanggulangan stunting dapat diidentifikasikan sebagai berikut;

Peran pemerintah provinsi adalah;

1) mensosialisasikan kebijakan prioritas pembangunan nasional, terkait dengan upaya percepatan pencegahan stunting.

2) merumuskan kebijakan daerah yang mendukung upaya percepatan pencegahan stunting di wilayah provinsi.

3) memberi bantuan tenaga teknis dan pelatihan untuk memperkuat kapasitas kabupaten/kota dalam melaksanakan Aksi Konvergensi/ Aksi Integrasi.

4) mendorong bupati/walikota berkomitmen dan melaksanakan secara aktif upaya pencegahan stunting.

5) mendorong pemerintah kabupaten/kota untuk menyiapkan sistem manajemen data yang terkait dengan pencegahan stunting.

6) memastikan hasil rembuk stunting berupa program/kegiatan sudah diakomodir dalam RKPD kabupaten/kota. Peran ini dilakukan pada saat evaluasi rancangan peraturan bupati/walikota tentang RKPD Kabupaten/Kota.

7) meningkatkan koordinasi antara OPD provinsi dengan OPD kabupaten/kota yang terkait dengan pelaksanaan Aksi Konvergensi/Aksi Integrasi.

8) memastikan program/kegiatan terkait dengan intervensi gizi spesifik dan gizi sensitif yang merupakan kewenangan provinsi dalam upaya percepatan pencegahan stunting pada rencana pembangunan daerah.

9) mengalokasikan belanja bantuan khusus untuk kabupaten/kota dan desa yang kurang mampu dari aspek pendanaan, dalam upaya percepatan pencegahan stunting.

10) memastikan intervensi gizi spesifik dan intervensi gizi sensitif tepat lokasi desa dan tepat kelompok sasaran. Peran ini dilakukan pada waktu evaluasi rancangan peraturan daerah tentang APBD kabupaten/kota 
11) melakukan pengawasan terhadap pelaksanaan kegiatan pencegahan stunting kabupaten/kota secara berkala.

12)melakukan penilaian kinerja kabupaten/kota dalam percepatan pencegahan stunting sebagai wakil pemerintah di wilayahnya masingmasing.

Adapun peran pemerintah kabupaten adalah:

1) merumuskan kebijakan daerah yang mendukung upaya percepatan pencegahan stunting; termasuk peningkatan peran camat dalam mengkoordinasikan perencanaan, pelaksanaan, dan pengendalian percepatan pencegahan stunting di wilayahnya.

2) mensosialisasikan kebijakan terkait upaya percepatan pencegahan stunting sebagai salah satu prioritas pembangunan nasional, khususnya kepada kecamatan dan desa.

3) mencanangkan komitmen bersama antara pemerintah daerah, desa dan unsur masyarakat untuk mendukung penuh upaya percepatan pencegahan stunting secara konsisten dan berkelanjutan.

4) menyelenggarakan pelatihan untuk peningkatan kapasitas OPD kabupaten/kota terkait dengan aparat desa dalam melaksanakan Aksi Konvergensi/Aksi Integrasi pencegahan stunting.

5) meningkatkan dan/atau membangun sistem manajemen data yang terkait dengan pencegahan stunting.

6) meningkatkan koordinasi dengan $\mathrm{K} / \mathrm{L}$, provinsi, desa, dan pihak lainnya yang terkait dengan pelaksanaan Aksi Konvergensi/Aksi Integrasi pencegahan stunting.

7) menyelenggarakan rembuk stunting tahunan dengan melibatkan unsur OPD provinsi terkait, desa, masyarakat, dan pihak lainnya yang terkait dengan upaya pencegahan stunting.

8) memastikan rencana program/kegiatan untuk intervensi gizi spesifik dan gizi sensitif hasil rembuk stunting yang telah disepakati, dimuat dalam RKPD/Renja OPD.

9) mengalokasikan dana bantuan khusus bagi desa-desa yang kurang mampu dari aspek pendanaan, dalam upaya pencegahan stunting. 
10) memaksimalkan pemanfaatan APBD dan Dana Alokasi Khusus (DAK) untuk program layanan intervensi gizi spesifik dan gizi sensitif, melalui proses penetapan DPA OPD.

11)memastikan bahwa APBD Desa telah sesuai dengan kebijakan bupati/walikota tentang upaya percepatan pencegahan stunting, serta serasi dan sinergi dengan program/kegiatan dalam RKPD kabupaten/kota. Peran ini dilaksanakan pada saat evaluasi rancangan peraturan desa tentang APBD-Desa.

12)melakukan pengawasan terhadap pelaksanaan kebijakan kegiatan pencegahan stunting yang dilakukan oleh desa.

13) melakukan penilaian kinerja desa dalam pencegahan stunting sebagai tugas pembinaan dan pengawasan.

14) mempublikasikan hasil capaian kinerja pencegahan stunting di wilayahnya

15) mengoordinasikan bantuan dari masyarakat, dunia usaha, donor, serta pihak lainnya yang terkait dalam upaya pencegahan stunting ke kelompok sasaran dan lokasi desa.

16)bertanggungjawab untuk meningkatkan pelayanan intervensi gizi spesifik dan gizi sensitif kepada kelompok sasaran.

\section{Faktor-faktor yang Memengaruhi Stunting dan Telah Dimasukkan dalam Dokumen Perencanaan dan Anggaran Dinas Kesehatan Kabupaten}

1. Pola Asuh, pola asuh diidentifikasi sebagai salah satu faktor yang memengaruhi kejadian stunting. Fenomena ibu bekerja dan anak-anak diasuh oleh orang lain (anggota keluarga atau pengasuh, dan lain-lain) menyebakan pengasuhan anak dinilai kurang berjalan dengan baik yang pada akhirnya berpengaruh pada tumbuh kembang anak yang bersangkutan.

2. Pola Makan, pola makan juga diidentifikasi sebagai salah satu faktor yang memengaruhi kejadian stunting. Pengetahuan ibu tentang pemberian pola makan pada anak dinilai memengaruhi kejadian stunting.

3. Pengetahuan Orang Tua terkait gizi, pengetahuan orang tua terkait gizi berkaitan dengan pemberian pola makan pada anak. Orang tua yang memiliki pengetahuan dan pemahaman gizi yang baik cenderung memperhatikan pemenuhan gizi dan asupan nutrisi anak-anaknya, demikian pula sebaliknya. 
4. Kesehatan Ibu. Kesehatan ibu, baik pada masa remaja maupun pada masa kehamilan, akan memengaruhi kondisi anak yang akan dilahirkan. Ibu dengan kesehatan dan kecukupan gizi yang baik akan melahirkan anak yang sehat dan terhindar dari resiko stunting. Demikian pula sebaliknya, ibu dengan kesehatan kurang baik, seperti menderita anemia dan kekurangan nutrisi, akan beresiko melahirkan anak stunting. Hal inilah yang menjadi alasan pertimbangan dimasukkannya perihal kesehatan ibu sebagai salah satu program perencanaan dalam menurunkan prevalensi stunting, yaitu melalui program PKPR (Program Kesehatan Peduli Remaja) berupa pemberian Tablet Tambah Darah (TTD) bagi para remaja putri SMP dan SMA, serta untuk ibu hamil.

5. Kesehatan Anak. Anak yang sakit atau sakit-sakitan, akan mengalami gangguan pada pertumbuhan dan tumbuh kembangnya, maka upaya pemeliharaan kesehatan anak dianggap penting sebagai upaya penurunan prevalensi stunting.

6. Partisipasi di Posyandu. Melalui kegiatan Posyandu, tumbuh kembang anak akan terpantau, sehingga permasalahan pada anak dapat segera terdeteksi sehingga dapat segera mendapatkan penanganan/tindaklanjut.

7. Faktor Lingkungan. Faktor lingkungan berkaitan dengan kesehatan, terutama dalam hal ini kesehatan ibu dan anak. Lingkungan yang sehat akan mendukung kesehatan ibu dan anak yang pada akhirnya berpengaruh pada penurunan resiko stunting.

8. Pemberian ASI Ekslusif. Pemberian ASI eksklusif pada bayi berkaitan dengan pemenuhan gizi bayi, terutama pada usia 0-6 bulan. Oleh karena itu, kampanye/sosialisasi terkait ajakan pemberian ASI eksklusif dinilai efektif untuk mengurangi tingkat stunting.

Semua faktor-faktor yang telah teridentifikasi tersebut, sudah dijadikan pertimbangan dalam membuat perencanaan dan penganggaran program-program dan kegiatan Dinas Kesehatan Kabupaten terutama dalam upaya penanggulangan dan penurunan prevalensi stunting di daerah. Hanya saja, karena keterbatasan anggaran, maka faktor-faktor tersebut dipilih dan diurutkan berdasarkan prioritas.

Selain faktor-faktor tersebut, terdapat faktor determinan lain yang merupakan faktor lintas sektor, yaitu: akses wilayah, pernikahan dini, faktor keturunan, faktor 
ekonomi, dan pendidikan orang tua. Oleh karena itu, untuk dapat menangani persoalan stunting secara efektif dan komprehensif, maka diperlukan kerjasama lintas sektor yang baik.

\section{Upaya Penanggulangan Stunting di Daerah}

Terdapat beberapa program dalam upaya penanggulangan stunting yang telah dilakukan, yaitu:

1. Pemberian Tablet Tambah Darah pada Ibu Hamil.

Dalam sesi Focus Group Discussion (FGD) yang dilakukan di Dinas Kesehatan Kabupaten, seorang informan (dengan jabatan pada bagian kesehatan keluarga dan gizi) mengatakan bahwa salah satu faktor penyebab stunting adalah ibu hamil yang mengalami anemia. Semua peserta FGD sepakat dengan pernyataan tersebut. Oleh karena itu, pemberian tablet tambah darah pada ibu hamil dinilai efektif dalam pencegahan stunting. Tablet tambah darah dikonsumsi minimal 90 tablet selama hamil. Namun demikian, Informan LL memberikan informasi bahwa secara distribusi, tablet tambah darah sudah tersalurkan dengan baik kepada sasaran, namun perihal pemanfaatannya, belum terukur sebab tidak ada pengawasan ataupun pemantauan mengenai diminum atau tidaknya tablet tambah darah yang telah diberikan kepada objek sasaran.

2. Pemberian Makanan Tambahan (PMT) Ibu Hamil Ibu hamil dengan status gizi tidak baik (Bumil KEK) sangat beresiko melahirkan anak stunting. Dengan demikian, pemberian PMT kepada bumil kek dinilai efektif untuk mencegah/mengurangi kejadian stunting.

3. Imunisasi Dasar Lengkap

Pemberian imunisasi dasar lengkap pada bayi dinilai mampu mencegah berbagai penyakit dan infeksi pada bayi. Bayi yang sering mengalami sakitsakitan apalagi hingga terkena infeksi akibat tidak mendapatkan imunisasi dasar lengkap, cenderung akan terganggu/terhambat tumbuh kembangnya sehingga berpotensi untuk stunting. Oleh karena itu, pemberian imunisasi dasar lengkap dinilai efektif dalam mengurangi tingkat stunting.

4. Vitamin A 
Pemberian vitamin A pada bayi dan balita dinilai memberikan manfaat sebagai anti oksidan dan mampu mencegah infeksi pada bayi dan balita. Bayi yang sering mengalami sakit ataupun infeksi, akan mengalami gangguan dan hambatan di dalam tumbuh kembangnya, yang pada akhirnya dinilai sebagai faktor yang dapat memengaruhi kejadian stunting. Oleh karena itu, pemberian vitamin A dinilai cukup efektif dalam mengurangi prevalensi stunting

5. Zinc

Bayi yang mengalami diare beresiko mengalami gangguan tumbuh kembang apabila sakit yang dialami berlangsung dalam waktu yang cukup lama dan berulang. Oleh karena itu, pemberian zinc sebagai obat diare dinilai cukup efektif dan kontributif dalam menurunkan resiko kejadian stunting.

6. Pemberian Makanan Tambahan (PMT) Balita

Pemberian Makanan Tambahan (PMT) Balita bagi anak yang sudah terlanjur stunting dianggap tidak akan memberikan pengaruh banyak dalam mengintervensi stunting. Manfaat PMT hanya sebagai perbaikan status gizi, tetapi tidak bisa mengintervensi/ mengurangi tingkat stunting

\section{Program Inovasi Kabupaten Bangka dan Bangka Barat dalam Penanggulangan Stunting}

Pada umumnya, program/kegiatan terkait stunting berasal dari program/kegiatan pemerintah pusat yang bersifat rutin/tahunan. Namun, di daerah-daerah prioritas, seperti Kabupaten Bangka dan Bangka Barat, anggaran yang dimiliki lebih besar, sehingga daerah-daerah tersebut dapat berinovasi membuat program-program sendiri terkait percepatan penurunan/penanggulangan stunting. Kabupaten Bangka Barat sebagai daerah dengan prevalensi stunting tertinggi di Provinsi Kepulauan Bangka Belitung telah melahirkan sebuah inovasi yang digagas oleh Dinas Kesehatan Kabupaten Bangka Barat yaitu program/kegiatan "Bedah Desaku", yaitu program menuju desa sehat, harmonis, energik, berprestasi, amanah dan takwa.

Beberapa inovasi dari Dinas Kesehatan dalam mengatasi seluruh permasalahan kesehatan di Bangka Barat adalah sebagai berikut:

1) PAK RT (Pendataan rumah tangga terintegrasi pis $P K$ )

2) TUAN JITA (Kartu Anak Negeri Sejiran Setason) 
3) DORELIS NAMPUNG (Dokter Spesialis Natak Kampung, Spesialis anak dan SPOG)

4) Pemeriksaan sampel air bersih di 15 desa stunting

5) Pemberian Bantuan Pemicuan STBM (Sabun dan alat-alat kebersihan)

Adapun Inovasi Dinas Kesehatan Kabupaten Bangka terkait stunting, yaitu:

1) Launching aplikasi e-posyandu (data balita by name by address untuk dipantau di posyandu oleh kader melalui android

2) Kelompok pendukung ASI

3) Rumah penimbangan siaga oleh kader

4) SMS bunda cerdas

5) SI RESTI CIKAR (Sistem informasi ibu hamil resiko tinggi, catat, informasikan, kunjungi dan atasi resiko)

6) Kelas edukasi ibu hamil dan menyusui

7) Kelas pemberian makan bayi dan anak (PMBA)

8) Arisan jamban ibu-ibu

\section{KESIMPULAN}

Hal yang harus diperbaiki agar program/kegiatan yang dilakukan bisa lebih efektif menurunkan stunting adalah dengan melakukan pendataan secara terpadu (data balita stunting by name by address) sehingga program/kegiatan yang dilakukan bisa tepat sasaran dan efektif dalam menanggulangi dan menurunkan stunting. Hal tersebut karena selama ini pendataan belum dilakukan secara terpadu, sehingga balita stunting tidak teridentifikasi secara jelas dan pasti, hanya berupa data gambaran umum saja, tidak berdasarkan by name by address balita stunting.

Kemudian selain itu, perlu dilakukan pemantauan atas program-program yang sudah diajalankan dalam rangka memastikan pencapaian tujuan program sebagaimana yang diharapkan. Misalnya, pemberian makanan tambahan untuk balita dan/atau keluarga miskin, makanan tambahan yang diberikan hendaknya benar-benar dipantau apakah dimakan atau tidak oleh objek sasaran. Hal ini pada akhirnya menyebabkan program yang dijalankan tidak mencapai target sasaran, sehingga upaya untuk penanggulangan dan penurunan stunting menjadi kurang 
efektif. Sementara itu, terkait besaran dan alokasi anggaran, besaran anggaran yang dialokasikan terkait penanggulangan stunting sudah dirasa memadai, hanya perlu pengoptimalan dalam pelaksanaannya saja agar dapat terlihat signifikansi hasil yang diharapkan.

\section{Rekomendasi/Saran}

1. Ada kerjasama dan sinergi lintas sektor terkait upaya penanggulangan stunting yang dimulai dari desa

2. Membuat tim khusus penanganan stunting dari pusat hingga ke daerah. Di provinsi sudah ada, tapi belum ada payung hukumnya, hanya berupa inovasi masing-masing daerah, sebaiknya ada instruksi dari pusat (dari presiden atau mendagri) yang bisa mengakomodir seluruh sektor terkait untuk pembentukan tim penanggulangan dan pencegahan stunting

3. Sebaiknya ada PMT khusus untuk anak stunting, karena anak stunting membutuhkan gizi/nutrisi khusus yang tidak sama dengan anak-anak lainnya yang tidak stunting.

\section{REFERENSI}

Elan Satriawan, Strategi Nasional Percepatan Pencegahan Stunting 2018-20124. Tim Nasional Percepatan Penanggulangan Kemiskinan (TNP2K), 22 November 2018

Izwardy, Doddy., 2019, Kebijakan dan Strategi Penanggulangan Stunting di Indonesia, Kementerian Kesehatan Republik Indonesia

Kementerian Koordinator Bidang Pembangunan Manusia dan Kebudayaan, 100 Desa Prioritas pada 10 Kabupaten Prioritas Stunting. Desember 2017

Kementerian Kesehatan Republik Indonesia., 2018, Hasil Utama Riskesdas 2018

Morris SS, Cogill, B, Uauy, R. Effective international action against undernutrition: why has it proven so difficult and what can be done to accelerate progress? Maternal and Child Undernutrions 5.The Lancet, Published Online January 17, 2008. 
$\mathrm{Ni}$ Ketut Aryastai, dan Ingan Tarigan.Kajian Kebijakan dan Penanggulangan Masalah Gizi Stunting di Indonesia. Buletin Penelitian Kesehatan, Vol. 45, No. 4, Desember 2017: 233-240

Pritasari, Kirana.,2018. Upaya Percepatan Penurunan Stunting: Evaluasi Pelaksanaan Tahun 2018 \& Rencana Tindak Lanjut Tahun 2019

Situasi Balita Pendek (Stunting) di Indonesia, Buletin Jendela Data dan Informasi Kesehatan Edisi 1 Semester I Tahun 2018, ISSN 2088-270 X

Syamsuadi, A. (2017). Membangun Demokrasi Pemerintahan di Riau Dalam Perspektif Budaya Melayu. Jurnal Dinamika Pemerintahan (JDP), 1(1), 1-10.

Tim Nasional Percepatan Penanggulangan Kemiskinan, 100 Kabupaten/Kota Prioritas untuk Intervensi Anak Kerdil (Stunting), 2017

TNP2K. 2017. "100 Kabupaten/Kota Prioritas Untuk Penanganan Anak Kerdil (Stunting)." 2.

Utama, Topik. "No Title." 